Dhaka Univ. J. Biol. Sci. 22(2): 145-154, 2013 (July)

\title{
A COMPARATIVE STUDY OF WATER QUALITY IN THE PERIPHERAL RIVERS OF DHAKA CITY
}

\author{
Mohammad Kamrul Hasan ${ }^{1}$, Md. Khalid Hasan² and Anwar Hossain* \\ Department of Fisheries, University of Dhaka, Dhaka-1000, Bangladesh
}

Key words: Comparative study, Water Quality, Peripherial rivers, Dhaka city, Bangladesh

\begin{abstract}
This study examined the present status of surface water pollution and a comparison of the quality of water in different seasons at different locations of the major river, around the Dhaka City. Field investigation was started from January, 2011 and sample collection was conducted six times at an interval of two months up to December, 2011. The observed value of different water quality parameters such as $\mathrm{pH}, \mathrm{DO}, \mathrm{BOD}, \mathrm{COD}$ and TDS were compared with the standards recommended by Department of Environment (DoE), Bangladesh and United States Environmental Protection Agency (USEPA). A simple ANOVA and Box-Cox study was also conducted to detect the variation of water quality in the major rivers. The study revealed that during the dry season especially in the months of December to February (winter), the higher values of parameters with respect to the acceptable limits of DoE and USEPA standard indicate the pollution of the river water samples and make the water unsuitable for various uses. Comparisons of abundance values demonstrated high significant difference $(\mathrm{p}<0.05)$ between the mean concentrations of respective parameters except $\mathrm{pH}$ at different locations in water source types. Water quality in Hagaribagh of Buriganga river and the Tongi railway bridge stations of Tongi khal was significantly more common polluted area than any other sites of selected water sources as the largest amounts of toxic chemicals are released here by the tannery and dyeing industries without any treatment.
\end{abstract}

\section{Introduction}

The peripheral rivers of Dhaka city are the most important watershed and crucial source of water for irrigation as well as for heavy and light industries, aquaculture, animal farming, municipal supply and wastewater dilution. However, the surface water along these rivers is known to be polluted due to municipal and industrial untreated wastewaters that are discharged into these rivers directly ${ }^{(1,2)}$. The banks of the rivers of Buriganga, Turag, Tongi khal and Balu have turned into unauthorized industrial districts. The river Buriganga passed in the southern side of Dhaka city through the more populated and industrial area. Domestic and industrial wastes of Dhaka city discharged

*Author for correspondence: <ahossain@du.ac.bd>. ${ }^{1}$ Disaster Risk Management Department, Bangladesh Red Crescent Society, Dhaka-1217, Bangladesh. ${ }^{2}$ Department of Soil Science, University of Chittagong, Chittagong, Bangladesh. 
into the river Buriganga by four main pathways. These are Hazaribagh tanneries, city drain along the river, Dholaikhal, and Pagla sewage treatment plant outfall. In addition, some major drainage channels drain the industrial and domestic wastes from the city center also discharged into the river Buriganga. The Turag and Tongi khal flow the western and northern side and Balu river in the eastern side of Dhaka city and around the industrial town of Tongi and Savar. A lot of tanneries, dyeing industries, brick fields, aluminum industries, battery manufacturing industries, pharmaceutical industries, soap industries, ink manufacturing industries, textile, paint, iron and steel workshops, $\mathrm{Pb}-\mathrm{Zn}$ melting industries are situated in the EPZ of Tongi area, around the river Turag and Tongi khal. The industrial area effluent falls on the river Turag and Tongi khal directly and through numerous distribution channels without any treatment. In fact, the rivers have become a dumping ground of all kinds of solid, liquid, and chemical waste of bank side population.

Thus, water quality of the rivers deteriorates increasingly and these pose a significant threat to our limited water supply by changing taste and odor, growth of aquatic weeds, aquatic life and wild life. Although some information on water quality of the river Buriganga do exist, but no comparison has yet been made with other river. In the present investigation, attempts have been made to compare the present status of surface water pollution and a statistical comparison of the quality of water in different seasons at different locations of the peripheral rivers of Dhaka city.

\section{Materials and Methods}

Dhaka is located in central Bangladesh at $23^{\circ} 42^{\prime} 0^{\prime \prime} \mathrm{N} 90^{\circ} 22^{\prime} 30^{\prime \prime} \mathrm{E}$ to $23^{\circ} 7^{\prime} 0^{\prime \prime} \mathrm{N} 90^{\circ} 37^{\prime} 5^{\prime \prime} \mathrm{E}$, on the upper alluvial deposits upstream of the confluence of two major rivers, the Brahmaputra and Meghana, covers a total area of 153.84 square $\mathrm{km}^{(3)}$. The detailed study areas were shown in Fig. 1.

Sample collection was conducted six times at three different stations (the definite sampling points of the downstream Buriganga river were Postagola $(\mathrm{P})$, Chadnighat $(\mathrm{C})$ and Hazaribagh $(\mathrm{H})$; the Turag River were Aminbazar (A), National Botanical Garden $(\mathrm{N})$ and Dubair Char (D) whereas the Tongi Khal (TK) were Masimpur (M), Tongi Railway Bridge (TRB) and Bhatulia (B) and the Balu river were Talia (T), Gazaria $(\mathrm{G})$ and Khalopara (K) identified as upstream) of each river at an interval of two months from January, 2011 to December, 2011. Water samples, to avoid the interference of the floating substances, were collected with the water sampler (Model:UWITEC, A-3510, USA) in the midstream at a depth of $0.5-1.5$ meters. The study period was divided into four seasonal groups: winter or northeast monsoon (December, January and February), pre-monsoon or summer (March, April and May), monsoon (June, July, August and September), post-monsoon (October and November). A short term field survey of rivers was carried out in order to locate the important sources of pollution. The sampling 
locations of surface water were selected on the basis of appropriate environmental significance as the sites of industrial complexes mainly chemical industries along the stretch of the river, vehicular traffic traverses around the particular site with considerable exhaust of particulates, fumes and gases from automobiles and boats, sites of the river where drainage effluents like domestic, municipal and hospital wastes were discharged.

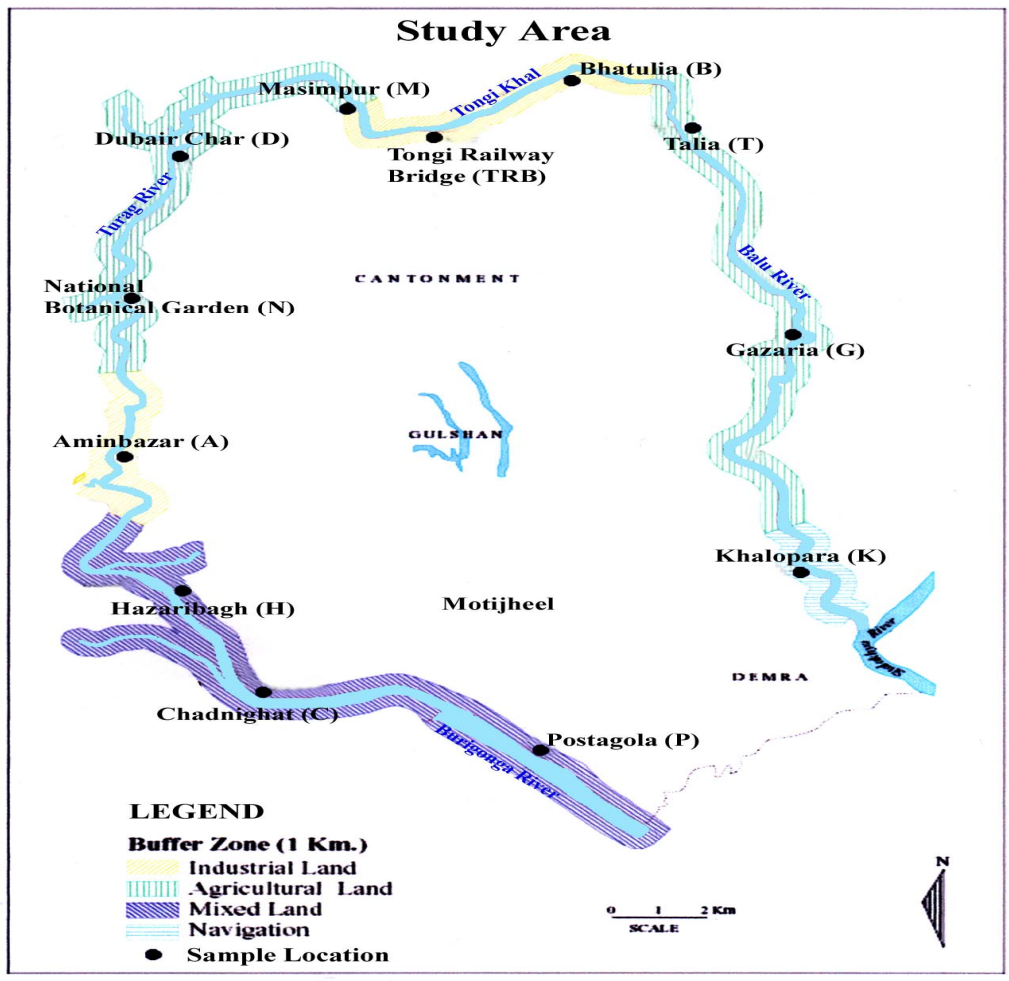

Fig. 1. Base map of the peripheral rivers of Dhaka city depicting sample location.

To determine the extent of pollution of the surrounding rivers of Dhaka city, various water quality parameters were monitored and a detailed field survey has been conducted within the study area. The following parameters were assessed by using APHA ${ }^{(4)}$ standard methods for examination of water and wastewater; $\mathrm{pH}$, dissolved oxygen (DO), biological oxygen demand (BOD), chemical oxygen demand (COD) and total suspended solids (TDS).

The data, thus, obtained were computed and subjected to statistical analysis. The significance of differences between seasons and locations were compared. NCSS statistical software has been used for the ANOVA with Tukey-Kramer and Duncan's multiple comparison tests with the standard value of water quality parameters proposed by Department of Environment, Bangladesh (DoE) and United States Environmental Protection Agency (USEPA). 
The Tukey-Kramer multiple comparison test is based on the assumption that the data are normally distributed, random, and independent that they have common variance. It is an exact alpha level test if the sample sizes are the same, and slightly conservative for unequal sample sizes ${ }^{(5)}$. An alpha level of 0.05 was used to judge significance of all tests discussed in this study. On the basis of these tests, it was determined that Box-Cox transformations of concentrations of BOD, COD and TDS was necessary to meet the normality assumption using maximum likelihood value (lambda $=-0.05)^{(6,7)}$. The mean values were also compared with water quality standards of DoE and USEPA (Table 2).

\section{Results and Discussion}

In the present investigation, the overall mean $\mathrm{pH}$ values of Buriganga, Balu, Tongi Khal and Turag river water samples were 7.75, 7.55, 7.51 and 7.35 for dry season and the highest average $\mathrm{pH}$ value was found during pre-monsoon $(\mathrm{pH}=7.85)$. This was due to high base saturations with low volume of water during dry season ${ }^{(8)}$. On the other hand, the $\mathrm{pH}$ of water was slightly low during monsoon (7.2 - 7.52) due to dilution effect and the lowest average $\mathrm{pH}$ value found during the month of August $(\mathrm{pH}=7.2)$. However, no significant difference exists ( $\mathrm{p} \leq 0.05)$ between the $\mathrm{pH}$ of dry and wet seasons for four rivers water, indicating that each of the four water resources are laden with pollutant load in almost equivalent degree irrespective of the season. But $\mathrm{pH}$ of Buriganga river $(\mathrm{H})$ in dry season was relatively higher than Tongi Khal (TRB) followed by Turag (M) and Balu River (K) and the direct opposite of this trend was observed during the wet season.

$\mathrm{DO}$ is very crucial for the survival of aquatic organisms and it is also used to evaluate the degree of freshness of a river (Fig. 2). DO in the river water showed marked variation at different sites. The mean values of DO in Buriganga river ( $2.35 \mathrm{mg} A$ in dry season) and (2.55 $\mathrm{mg} /$ in wet season) were significantly ( $\mathrm{p}>0.05$ ) lower than that of Tongi Khal (3.1 and $3.55 \mathrm{mg} /$ ), Turag river ( 3.5 and $3.55 \mathrm{mg} /$ ) and Balu river water ( 3.1 and $3.60 \mathrm{mg} /$ ), respectively. The DO value at upstream river ranged from $4.1-1.73 \mathrm{mg} /$ in the months of July and January, respectively. The DO level decreased sharply in downstream of the rivers with average values of 2.7 and $1.2 \mathrm{mg} \Lambda$. The persistence DO deficit indicated that the de-oxygenating rate due to biological decomposition of organic matter is higher than re-oxygenation from the atmosphere or probably due to the oxygen demanding industrial wastes into the water body ${ }^{(9,10)}$.

As it was observed from the analysis, the average DO level at Hazaribagh and Chandnighat in Buriganga and Tongi railway bridge in Tongi Khal, which constitute 2.43 and $2.35 \mathrm{mg} /$ on an average, respectively, were considerably less common than any other rivers around Dhaka city (Fig. 3). The less polluted area is Dubair Char in Turag River

and Gazaria in Balu river. It is evident that the concentration of DO is low where the industries are predominant and found high in the non-agricultural areas. 


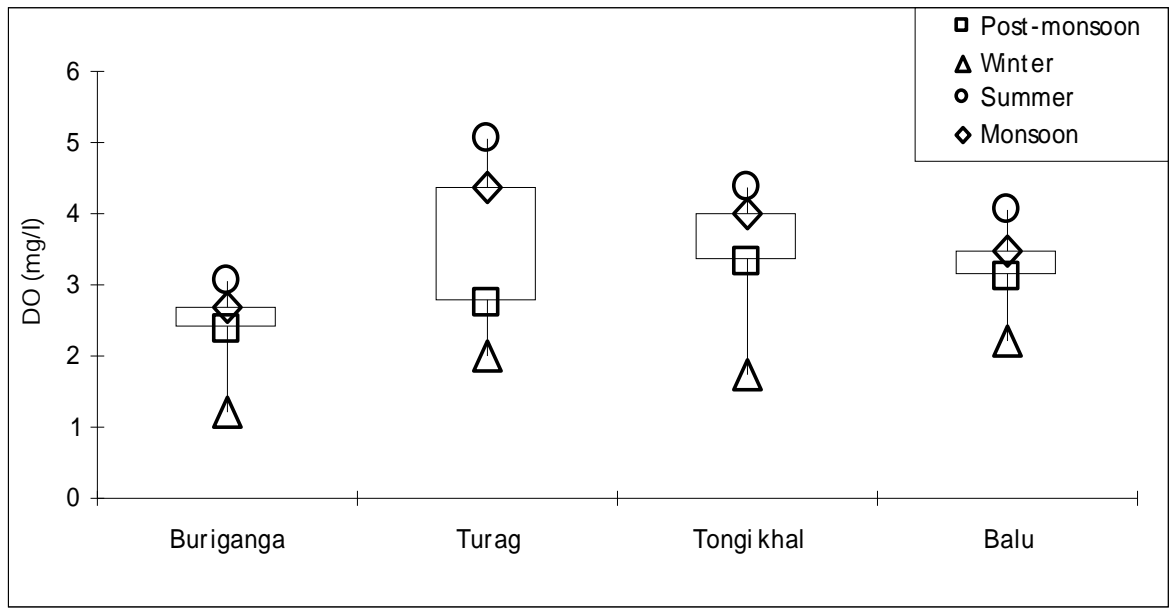

Fig. 2. Seasonal variations of DO level in four rivers.

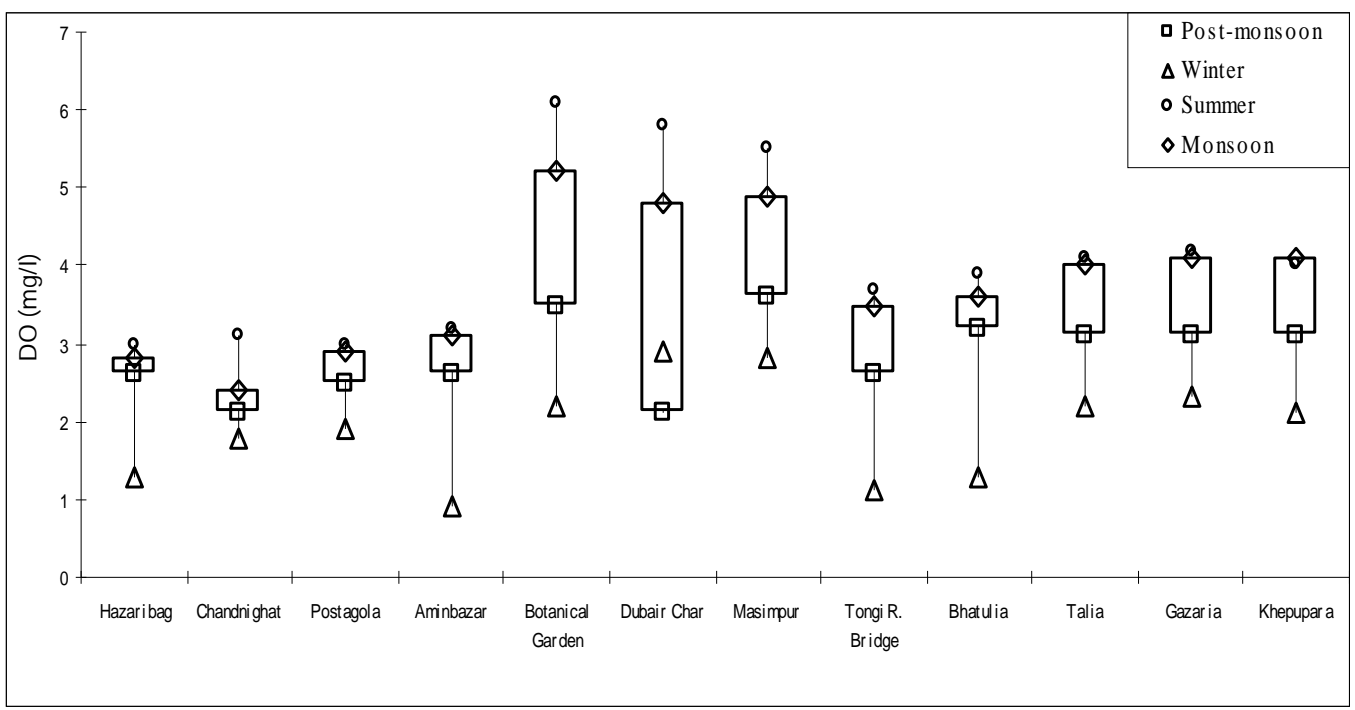

Fig. 3. Seasonal variations of DO level of sampling stations in four rivers.

In the present study a good seasonal variation in BOD concentration is found in all the four rivers. The lowest value $(12 \mathrm{mg} /)$ was found in Turag river in monsoon. The highest value $(165 \mathrm{mg} \Lambda)$ of BOD was detected in Buriganga river in all seasons compared to the Balu river ( $55 \mathrm{mg} \Lambda)$, Turag ( $52 \mathrm{mg} \Lambda$ ) and Tongi Khal $(78 \mathrm{mg} \Lambda)$ in dry season. The results indicate that the water body had suffered deterioration and degradation owing to the continuous discharge of effluent. Overall, the concentration was found higher in dry season and lower was observed during wet period in the four rivers (Fig. 4).

The chemical oxygen demand (COD) is a measure of oxygen equivalent to the organic matter content of the water susceptible to oxidation and thus is an index of 
organic pollution in river (11). This study revealed that the value of COD was the highest (310 $\mathrm{mg} /$ ) at Hazaribag and Tongi railway bridge sites $(280 \mathrm{mg} \Lambda)$ in winter and the lowest at Gazaria and Khepupara $(155 \mathrm{mg} /)$ in pre-monsoon which is absolutely beyond standards. The discharge of highly oxidized chemicals from different industrial units at these areas serves as the main cause for high value of COD. The concentration of BOD and COD were higher in the Buriganga River in dry season as it has flown through the densest urbanized and big or small industrialized area and most of the leather industries are situated near the bank of this river. The reasons to mounting the concentration are the direct disposal of municipal industrial wastewater into this river.

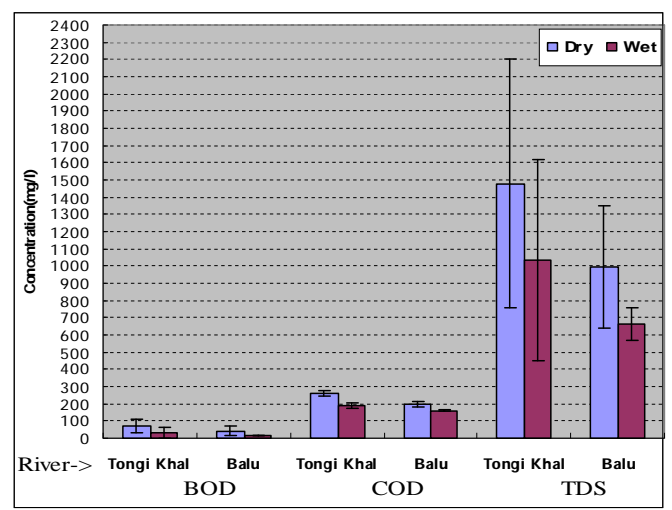

(a)

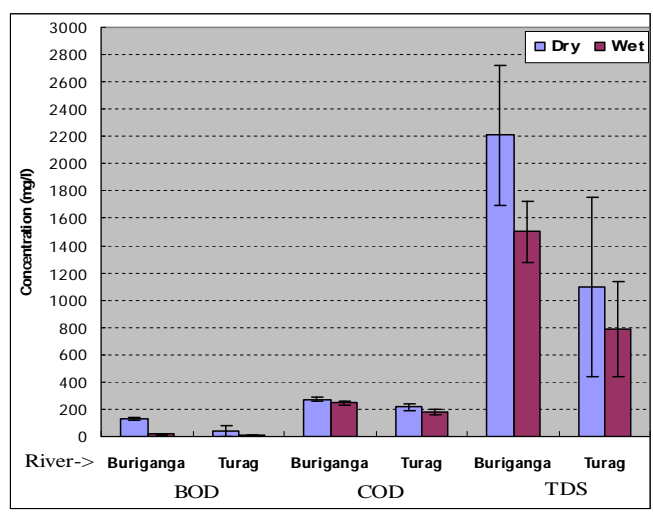

(b)

Fig. 4. Seasonal variation of different water quality parameters in peripheral rivers of Dhaka city.
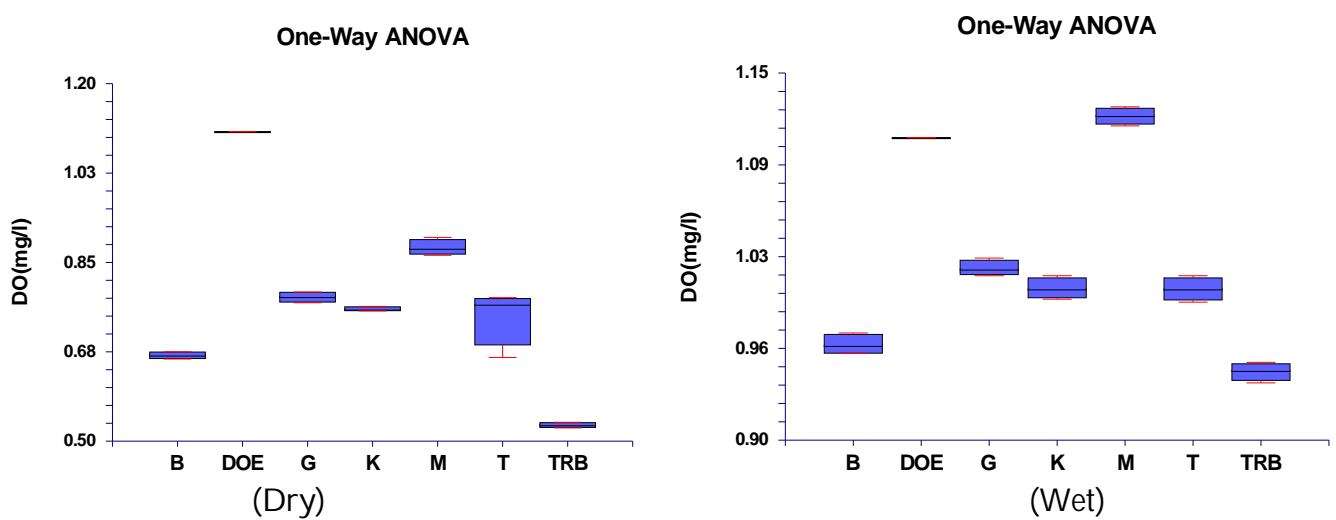

Fig. 5. Comparison of transformed DO concentration and ANOVA ( $p<0.05)$ with DoE standard (Upstream).

The total dissolved solids (TDS) are an indication of the degree of dissolved substances such as metal ions in the water. The mean values of TDS in Buriganga river $(-x=2200)$ was significantly $(P>0.05)$ greater than Tongi Khal $(-x=1490)$, Turag river 
$(-x=1100)$ and Balu river water $(-x=1000)$ for dry season and 1500, 1040, 800 and 680 $\mathrm{mg} /$ for wet season. The data revealed that significant $(\mathrm{p}>0.05)$ differences in TDS levels was observed for the two seasons (Fig. 4). In this study the main sources for elevated TDS level especially in Balu and Turag river water are fertilizers and pesticides runoff, decomposed leaves and silt. On the other hand, residential runoff, leaching of soil contamination and point source of water pollution i.e. discharge from industrial and sewage treatment plant particularly during dry season with low water level is the primary sources to increase the TDS level in the river Buriganga and Tongi Khal. However, relatively low values were found during wet season (Fig. 4) notably in monsoon might due to the polluted water is diluted with the rain water ${ }^{(12)}$.
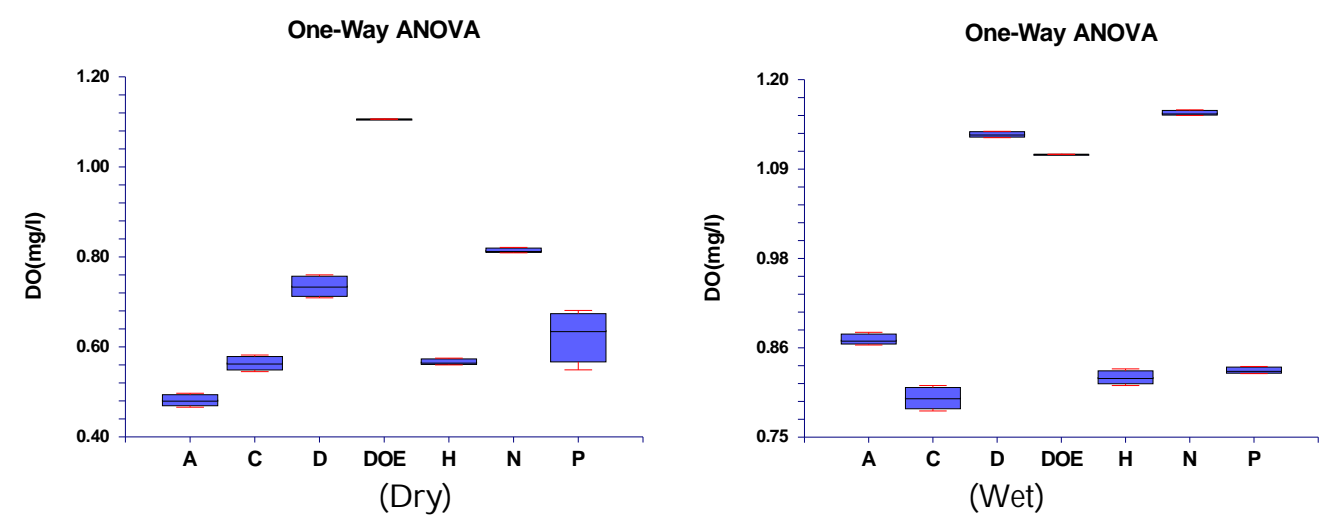

Fig. 6. Comparison of transformed DO concentration and ANOVA $(\mathrm{p}<0.05)$ with DoE standard (Downstream).
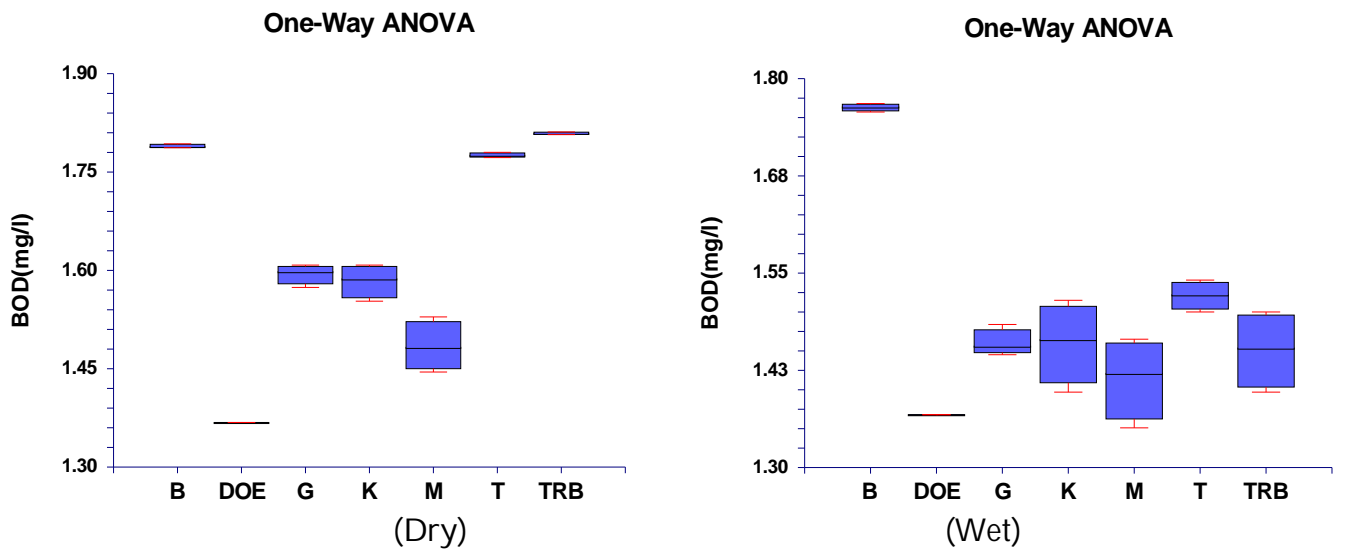

Fig. 7. Comparison of transformed BOD concentration and ANOVA $(\mathrm{p}<0.05)$ with DoE standard (Upstream). 

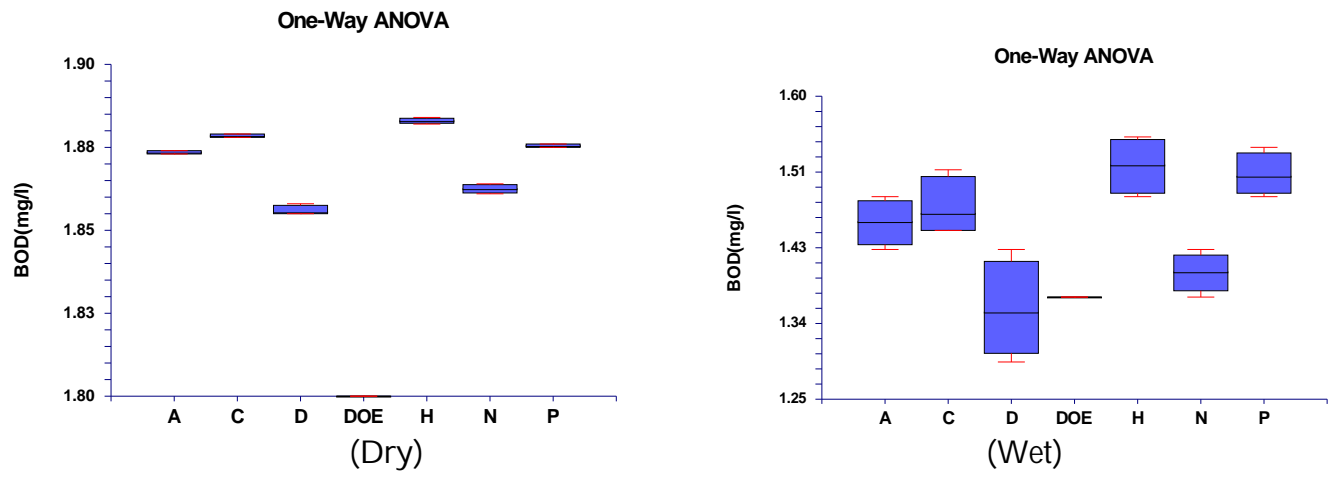

Fig. 8. Comparison of transformed BOD concentration and ANOVA $(p<0.05)$ with DoE standard (downstream).

One way ANOVA was used to detect differences between watersheds. Because of the severe "skewness" of the data, common in water quality data affected by non point and point sources of pollution, ANOVA's were run on rank-average transformed data for comparison of mean concentration distributions. An alpha value of 0.05 was used for statistical significance. If a significant difference among group mean was detected, Tukey's multiple comparison test was used on the rank transformed data to determine where differences were located (Table 1). The computed F ratio of 1312.08 (dry) and 12.86 (wet) with 6 and 18 degree of freedom, is seen to be significant $(p<0.05)$.

Table 1. Statistical comparison of BOD in different sampling stations of upstream and downstream river with DoE and USEPA.

\begin{tabular}{|c|c|c|c|c|c|c|c|c|c|}
\hline & & \multicolumn{4}{|c|}{ Tukey } & \multicolumn{4}{|c|}{ Duncuns } \\
\hline & & \multicolumn{2}{|r|}{ Dry } & \multicolumn{2}{|c|}{ Wet } & \multicolumn{2}{|r|}{ Dry } & \multicolumn{2}{|c|}{ Wet } \\
\hline & & Mean & *SDF(low-high) & Mean & *SDF & Mean & *SDF & Mean & *SDF \\
\hline \multirow[t]{2}{*}{$\begin{array}{l}\text { Ups- } \\
\text { tream }\end{array}$} & DoE & 1.368 & $\begin{array}{l}\mathrm{M}, \mathrm{K}, \mathrm{G}, \mathrm{T}, \mathrm{B} \\
\mathrm{TRB}\end{array}$ & 1.368 & $\mathrm{~T}, \mathrm{~B}$ & 1.368 & $\begin{array}{l}\text { M,K,G,T,B } \\
\text {,TRB }\end{array}$ & 1.368 & $\begin{array}{l}\text { TRB, G, T, } \\
\text { B }\end{array}$ \\
\hline & USEPA & 1.553 & $\mathrm{~T}, \mathrm{~B}, \mathrm{TRB}$ & 1.553 & $\mathrm{M}, \mathrm{B}$ & 1.553 & $\begin{array}{l}\text { M, T, B, } \\
\text { TRB }\end{array}$ & 1.553 & $\begin{array}{l}\text { M, TRB, } \\
\text { G, K, B }\end{array}$ \\
\hline \multirow[t]{2}{*}{$\begin{array}{l}\text { Down- } \\
\text { stream }\end{array}$} & DoE & 1.8 & $\begin{array}{l}\mathrm{D}, \mathrm{N}, \mathrm{A}, \mathrm{P}, \mathrm{C}, \\
\mathrm{H}\end{array}$ & 1.368 & $\mathrm{P}, \mathrm{H}$ & 1.8 & $\begin{array}{l}\mathrm{D}, \mathrm{N}, \mathrm{A}, \mathrm{P}, \\
\mathrm{C}, \mathrm{H}\end{array}$ & 1.368 & $\mathrm{~A}, \mathrm{C}, \mathrm{P}, \mathrm{H}$ \\
\hline & USEPA & 1.789 & $\begin{array}{l}\mathrm{D}, \mathrm{N}, \mathrm{A}, \mathrm{P}, \mathrm{C}, \\
\mathrm{H}\end{array}$ & 1.553 & $\mathrm{D}, \mathrm{N}$ & 1.789 & $\begin{array}{l}\mathrm{D}, \mathrm{N}, \mathrm{A}, \mathrm{P}, \\
\mathrm{C}, \mathrm{H}\end{array}$ & 1.553 & $\mathrm{D}, \mathrm{N}, \mathrm{A}, \mathrm{H}$ \\
\hline
\end{tabular}

*SDF denotes the significant difference of the sampling stations in a rank order (low to high) with DoE and USEPA standard.

The Multiple comparison using Tukey-Kramer and Duncan's multiple range test revealed that compared to DoE and USEPA standard, the stations Hazaribag and Chadnighat in downstream and Tongi railway bridge and Bhatulia in upstream of the catchments were the most significantly different ( $p>0.05)$ (Figs 5 - 8). 
In this study, the water quality parameters in the Hazaribag, Tongi railway bridge and Aminbazar stations of Buriganga river, Tongi Khal and Turag river, respectively showed that the concentration is much higher than the standard permissible limit given by the DoE of Bangladesh (Table 2). The pollution level of Balu river is less compare to the rivers Buriganga, Turag and Tongi Khal as it is passed through non-industrialized and less urbanized area. The condition for this grave situation, unplanned urbanization and industrialization, lack of effecting pollution control measures and strict enforcement resulting the disposal of municipal and industrial waste effluent into riverine system has given rise to heavily localized pollution.

Table 2. Standards for water (Source: DoE, Guide to the Environmental Conservation Act 1995 and Rules 1997, Department of Environment, Bangladesh.)

\begin{tabular}{lccc}
\hline Parameters & Drinking water & Inland surface water & Irrigation water \\
\hline Temp. OC & $20-30$ & 40 & $20-30$ \\
pH & $6.5-8.5$ & $6.0-9.0$ & $6.5-8.5$ \\
DO $(\mathrm{mg} /)$ & 6 or more & $4.5-8.0$ & 5 or more \\
TDS $(\mathrm{mg} /)$ & 1000 & 2100 & $450-2000$ \\
\hline
\end{tabular}

The present study can be concluded that the surface water quality of these major rivers around Dhaka city, posed a serious threat to public life and ecosystem.

\section{References}

1. Subramanian B 2004. Water quality in South Asia. Asian J. Water Env. Pol. 1(1\&2): 41-54.

2. Karn SK and Harada, H. 2001. Surface Water Pollution in Three Urban Territories of Nepal, India, and Bangladesh. Env. Man. 28(4): 483-496.

3. Statistical Year Book of Bangladesh. Bangladesh Bureau of Statistics 2001. pp. 16-17

4. APHA, American Public Health Association 1998. Standard methods for examination of water and wastewater. Washington, D.C. APHA.

5. Rebecca N, Bushon and Koltun 2004. Microbiological water quality in relation to watercontact recreation, Cuyahoga River, Ohio. Water Resource Investigation Report 0 3-4333. US. Geological Survey, Virginia.

6. Box GEP and DR Cox 1962. An analysis of transformation. J. R. Stat. Soc. B. 26:211-252.

7. Peng L., S Yirong, N Zheng and W Jinshiui 2007. Geostatistical analysis and risk assessment on TP and TN in the dongting lake plain area, China. J. Env. Quality 36: 935-942.

8. Moniruzzaman M, S Elahi and A Jahangir 2009. Study on Temporal Variation of Physicochemical Parameters of Buriganga River Water through GIS (Geographical Information System) Technology. Bangladesh J. Sci. Ind. Res. 44(3): 327-334.

9. Gasim M, S Mir and T Chek 2007. A Physico-chemical Assessment of the Bebar river, Pahang, Malaysia. Global J. Env. Res. 1(1): 07-11. 
10. Joseph R. and P Tessy 2010. Water quality and pollution status of Chalakudy River at Kathikudam, Thrissur District, Kerala, India. Nature Env. Pol. Tech. 9(1): 113-118.

11. Khaiwal R. Ameena, Minakshi, Monika, Rani, and A Kaushik 2003. Seasonal variations in physicochemical characteristics of River Yamuna in Haryana and its ecological bestdesignated use. J. Env. Mon. 5: 419-426.

12. Begum D. and K Tanvir 2010. Water Quality Aspects in and around Dhaka City. Proceeding of International Conference on Environmental Aspects of Bangladesh. Japan.

(Manuscript received on 13 April, 2013; revised on 8 June, 2013) 